\title{
MÁY LẠNH HẤP PHỤ SỬ DỤNG NHIẸT THẢI CỦA ĐỘNG CƠ ĐỐT TRONG ĐỂ ĐIỀU HÒ̀A KHÔNG KHÍ TRONG Ồ TÔ
}

\author{
LÊ VĂN HIÊN, NGUYỄN THI KIM LIÊN \\ Khoa Công nghệ Nhiệt Lạnh, Truờng Đại học Công nghiệp Thành phố Hồ Chi Minh \\ nguyenthikimlien_nl@iuh.edu.vn
}

Tóm tắt. Hoạt động của nền kinh tế tiêu thụ phần lớn nhiên liệu hóa thạch, trong đó ngành giao thông vận tải chiếm $22 \%$ lượng nhiên liệu này. Khí thải của các phương tiện giao thông, đặc biệt là lượng ôtô ngày càng tăng mạnh ở Việt Nam sẽ làm tăng nhanh ô nhiễm không khí. Đây cũng là nguyền nhân gây nên quá trình biến đổi khí hậu ngày càng trầm trọng. Để góp phần tiết kiệm tiêu thụ nhiên liệu của động cơ ôtô, chúng tôi đã khảo sát nguồn nhiệt năng từ khí thải của ôtô để cung cấp cho máy lạnh hấp phụ rồi liên kết nguồn lạnh này với điều hòa không khí trong ôtô. Bài báo này giới thiệu quá trình đó.

Từ khóa. Máy lạnh hấp phụ, điều hòa không khí trong ôtô, tiết kiệm năng lượng, tận dụng khí thải, nhiệt thải.

\section{ADSORPTION AIR CONDITIONER USING WASTE HEAT OF INTERNAL COMBUSTION ENGINE FOR FOR CAR AIR CONDITIONING}

\begin{abstract}
In order to save the fuel consumption of car engines and reduce environmental pollution, the heat source from the exhaust gas of the car is utilized to supply heat the adsorption cooling system for air conditioning purpose in the car cabin. This article is carried out in a two-part study. The first part is that survey waste heat from car engines which could supply heat for adsorption air conditioner with suitable working pair. In second part, the thermodynamic processes of adsorption cooling cycle for car air conditioning and simple calculation are discussed in this article.
\end{abstract}

Keywords. The adsorption air conditioner, air conditioner of cars, saving energy, make use of waste gas and waste heat.

\section{GIÓ́I THIỆ}

Theo bài "Ô tô, xe máy gây ô nhiễm không khí nghiêm trọng" trên cổng thông tin điện tử của bộ giao thông vận tải (mt.gov.vn) nói về ô nhiễm môi trường do khí thải của ô tô [1] thì giao thông vận tải là một trong những hoạt động chủ yếu phát thải khí nhà kính (tác nhân gây nên sự nóng lên toàn cầu), lớn thứ 3 sau ngành năng lượng và nông nghiệp, chiếm 18,38\% tổng lượng khí nhà kính thải vào bầu khí quyển hàng năm. Trong giai đoạn 2011- 2016, các hoạt động giao thông vận tải ở Việt Nam tiêu thụ một lượng lớn năng lượng, chiếm $30 \%$ tổng nhu cầu năng lượng quốc gia, $60 \%$ tổng nhiên liệu tiêu thụ và tăng $10 \%$ mỗi năm. Với xu hướng số lượng phương tiện giao thông gia tăng mạnh mẽ qua các năm, nguồn đóng góp đáng kể gây ô nhiễm không khí, dẫn đến biến đổi khí hậu ngày càng trầm trọng. Công việc nghiên cứu tận dụng nhiệt thải để tiết kiệm năng lượng nhằm góp phần giảm lượng khí thải gây hiệu ứng nhà kính đang được đẩy mạnh.

Hệ thống điều hòa trên xe ô tô là cần thiết nhằm bảo đảm tiện nghi thoải mái cho người ngồi trên xe nhưng hệ thống điều hòa này tiêu thụ năng lượng đáng kể. Nghiên cứu của Barrault và các cộng sự [2] chỉ ra rằng, năng lượng tiêu tốn cho điều hòa không khí chiếm từ 2,3 đến $11,2 \%$ tổng năng lượng tiêu thụ. Gần $70 \%$ năng lượng sơ cấp từ nhiên liệu được giải phóng trong động cơ đốt trong được phát tán qua nước làm mát động cơ và khí thải dưới dạng nhiệt thải [2], [3]. Do vậy, ngoài việc hoàn thiện các quá trình chuyển hóa nhiệt năng do đốt cháy nhiên liệu trong động cơ thành cơ năng và điện năng, việc sử dụng nhiệt thải cấp cho máy lạnh hấp phụ để điều hòa không khí cũng đang được quan tâm nghiên cứu. Bài viết này sẽ mô tả nguyên lý hoạt động của máy lạnh hấp phụ và đề xuất lựa chọn kết cấu của nó phục vụ cho điều hòa không khí trong ô tô.

\section{CÔNG NGHẸ HIỆN TẠI}

Trên cơ sở nhiệt động học kỹ thuật, quá trình chuyển hóa nhiệt năng không những thành công cơ học mà 
còn thực hiện quá trình làm lạnh và điều hòa không khí được biểu diễn trên sơ đồ hình 1 dưới đây.

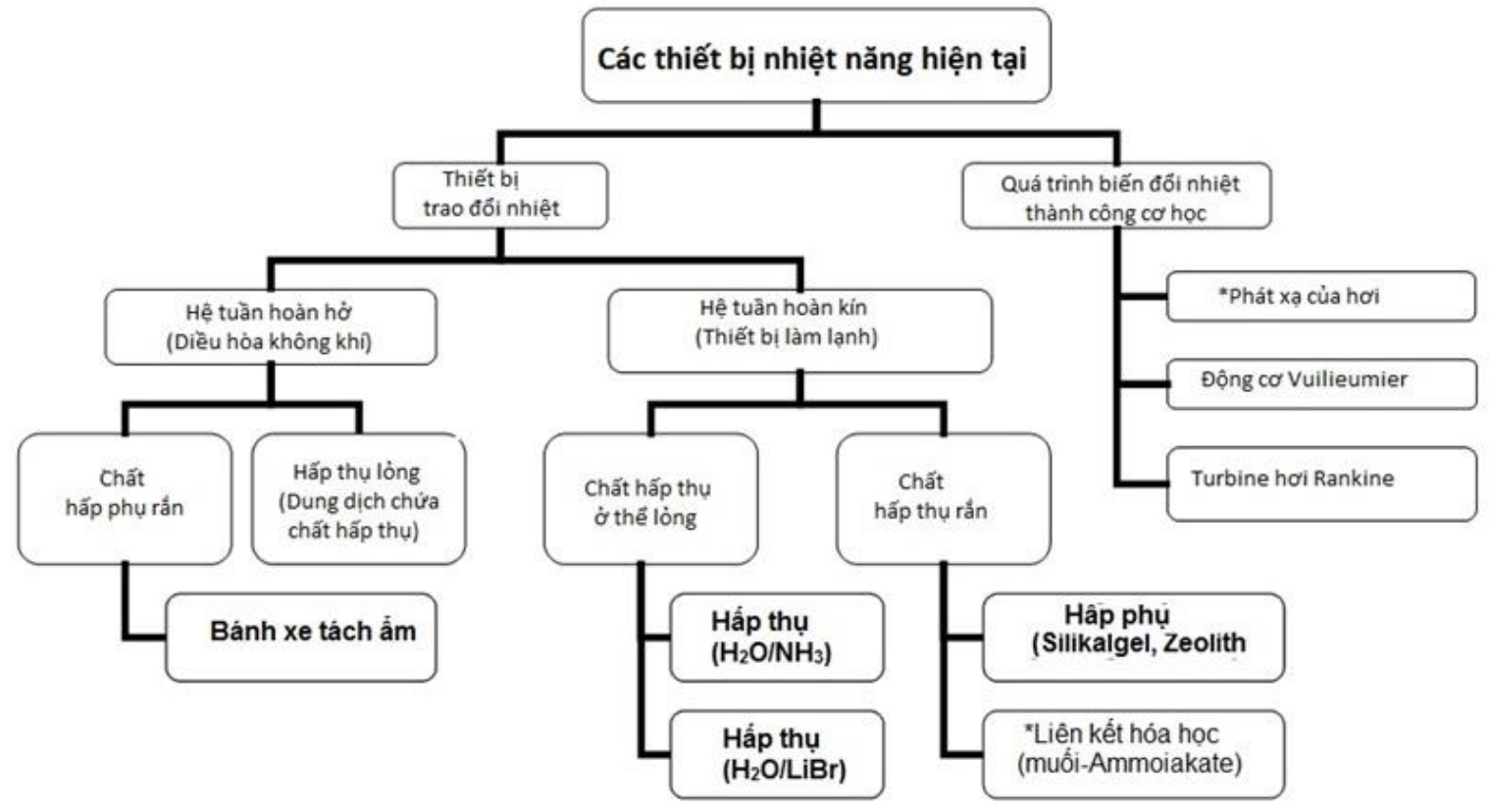

Hình 1: Các phương pháp biến hóa năng lượng. (Ghi chú: Các ô có dấu * chỉ mới ở dạng sơ khai, đang thử nghiệm) [4]

Trên hình 1, phía bên phải thể hiện quá trình biến đổi nhiệt năng thành công cơ học, còn phía bên trái là các thiết bị chuyển hóa nhiệt năng để làm lạnh và điều hóa không khí. Đối với các thiết bị trao đổi nhiệt chuyển hóa nhiệt năng, có 2 hệ tuần hoàn hở và tuần hoàn kín. Ở đây, tìm hiểu theo hướng dùng nhiệt năng để vận hành quá trình làm lạnh trong hệ thống tuần hoàn kín nhờ chất hấp thụ ở thể lỏng hoặc chất hấp phụ ở thể rắn.

\subsection{Quá trình làm lạnh của máy lạnh hấp thụ}

Phương pháp làm lạnh và điều hòa không khí bằng nhiệt năng so với làm lạnh thông thường sử dụng máy nén chạy bằng động cơ điện có một vài khác biệt. Một bên là sử dụng máy nén để làm động lực cho môi chất lạnh lưu động tuần hoàn. Trong quá trình lưu động, môi chất lạnh thay đổi trạng thái của nó rồi hoá hơi ở áp suất nhất định, tại đó nhiệt độ hóa hơi tương ứng với áp suất hóa hơi. Có thể so sánh sự khác nhau giữa hai loại máy lạnh qua mô tả ở hình 2 . Ở đây, bên trái là máy lạnh dùng điện năng để vận hành máy lạnh máy nén thông thường và bên phải là máy lạnh hấp thụ. Như vậy, máy lạnh hấp thụ chủ yếu dùng nhiệt năng để vận hành quá trình làm lạnh, nó có vai trò như máy nén trong quá trình làm lạnh.

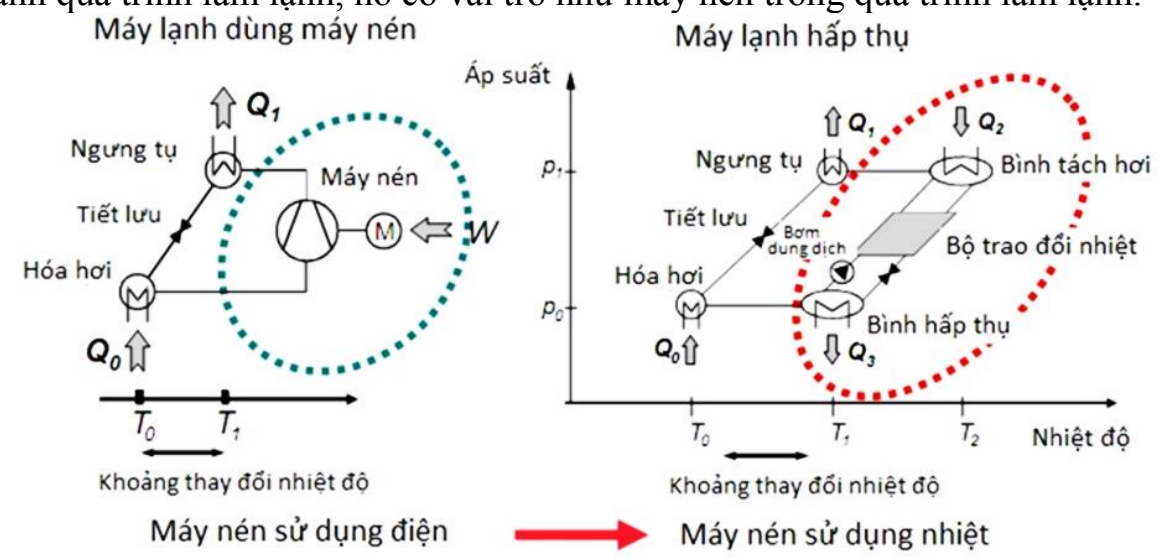

Hình 2: Sơ đồ diễn tả sự khác nhau giữa 2 phương pháp làm lạnh [4]

Công nghệ làm lạnh sử dụng nhiệt năng tái tạo làm việc trên nguyên lý của máy lạnh hấp thụ (đối với chất hấp thụ lỏng) hoặc hấp phụ (đối với chất hấp phụ rắn). Sơ đồ quá trình lưu động cơ bản của máy làm lạnh hấp thụ một cấp được thể hiện trong hình 3. 


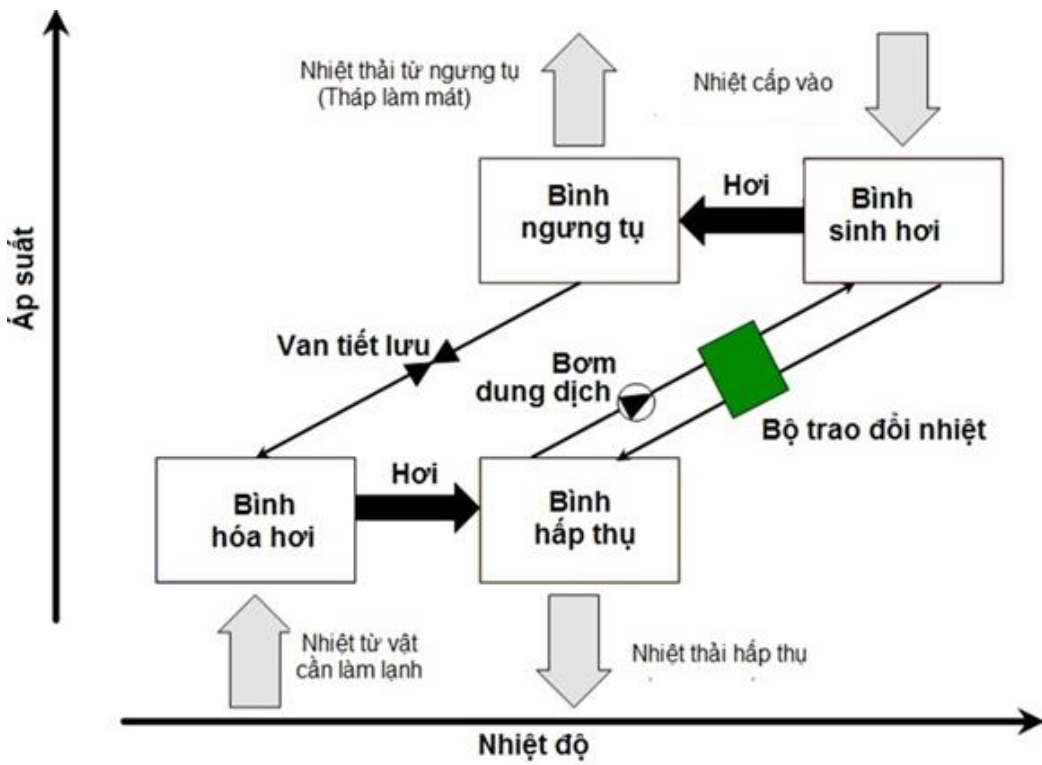

Hình 3: Sơ đồ máy lạnh hấp thụ 1 cấp [4]

Trong quá trình tuần hoàn của dung dịch hấp thụ, nồng độ dung dịch thay đổi với hai dải nồng độ: dung dịch loãng tương ứng với nồng độ môi chất lạnh thấp và dung dịch đặc tương ứng với nồng độ môi chất lạnh cao.

Như vậy, sẽ tồn tại hai cực điểm là điểm có nồng độ cao nhất và thấp nhất. Hiện tại có 2 cặp môi chất được sử dụng rộng rãi. Cặp thứ nhất là $\mathrm{LiBr} / \mathrm{H}_{2} \mathrm{O}$, trong đó $\mathrm{LiBr}$ là dung dịch hấp thụ, $\mathrm{H}_{2} \mathrm{O}$ là môi chất lạnh. Khi sử dụng cặp $\mathrm{LiBr} / \mathrm{H}_{2} \mathrm{O}$, độ lạnh sâu nhất chỉ đạt tối đa chỉ gần $0^{\circ} \mathrm{C}$. Cặp thứ 2 là $\mathrm{NH}_{3} / \mathrm{H}_{2} \mathrm{O}$, trong đó $\mathrm{NH}_{3}$ là môi chất lạnh, $\mathrm{H}_{2} \mathrm{O}$ là dung dịch hấp thụ. Với $\mathrm{NH}_{3}$ là môi chất lạnh thì nhiệt độ làm lạnh có thể đạt tới nhiệt độ âm $\left(-60^{\circ} \mathrm{C}\right)$. Hình 4 là sơ đồ khối của máy lạnh hấp thụ.

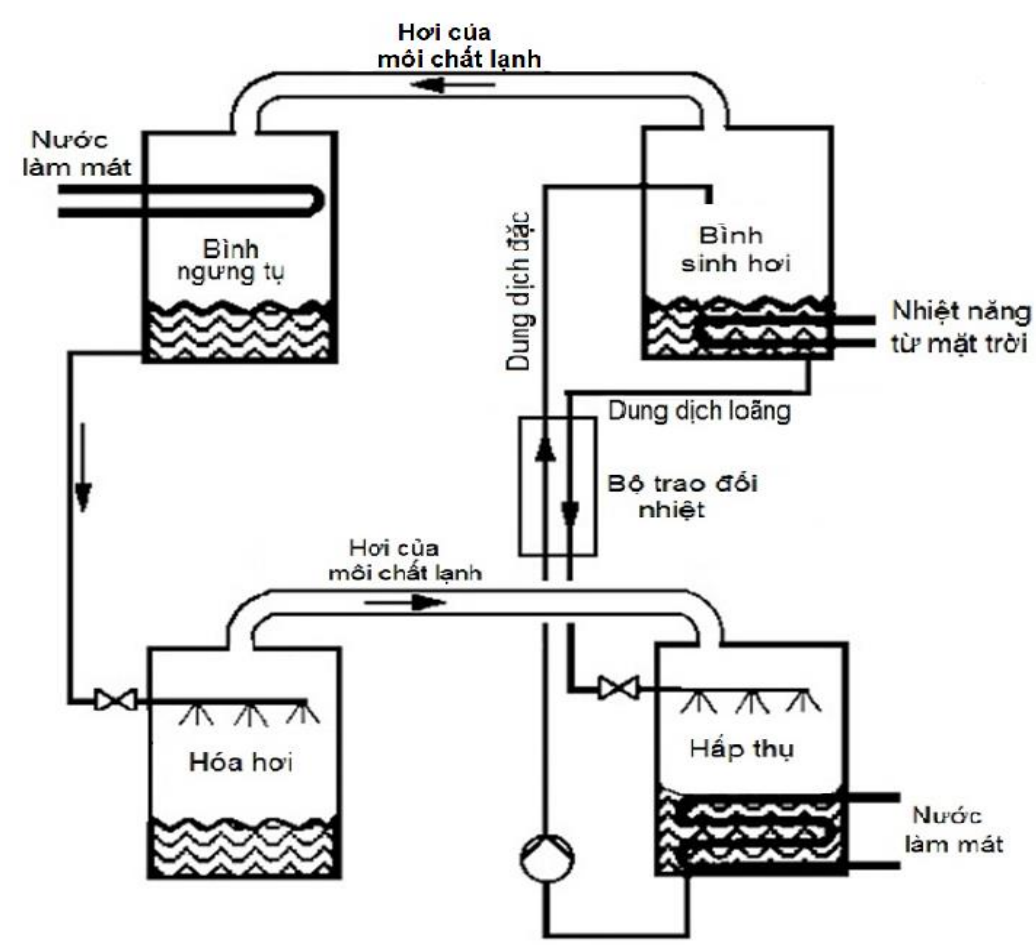

Hình 4: Sơ đồ khối của máy lạnh hấp thụ [5]

Như vậy, máy lạnh hấp thụ có những thành phần như sau: buồng hóa hơi; bình hấp thụ; bơm dung dịch; bình sinh hơi; van tiết lưu dung dịch và môi chất lạnh và cuối cùng là bình ngưng tụ. 
Khi nhiệt năng cấp cho bình sinh hơi, hơi của môi chất lạnh bay ra từ dung dịch rồi qua bình ngưng tụ. Tại đó, hơi được làm mát rồi ngưng tụ thành lỏng, nó tiếp tục qua van tiết lưu, hóa hơi trong buồng lạnh. Tiếp theo, hơi môi chất lạnh đó được dung dịch loãng trong bình hấp thụ, hấp thụ vào dẫn đến nồng độ môi chất lạnh trong bình sinh hơi sẽ giảm dần và trong bình hấp thụ sẽ tăng dần. Dung dịch loãng trong bình sinh hơi sẽ qua van tiết lưu trở về bình hấp thụ và dung dịch đặc trong bình hấp thụ sẽ được bơm dung dịch đưa vào bình sinh hơi. Sự lưu động của hơi môi chất lạnh do chênh lệch áp suất giữa bình sinh hơi và buồng hóa hơi. Và từ buồng hóa hơi tới bình hấp thụ do áp lực của cặp môi chất. Duy chỉ có bơm dung dịch là phần động sử dụng nguồn điện, các bộ phận còn lại do nguồn nhiệt cung cấp nên luôn tĩnh tại, không gây tiếng ồn do hoạt động của máy nén.

\subsection{Quá trình làm lạnh của máy lạnh hấp phụ}

Một máy lạnh hấp phụ đơn giản bao gồm bình hóa hơi, bình hấp phụ và bình ngưng tụ như mô tả trên hình 5.
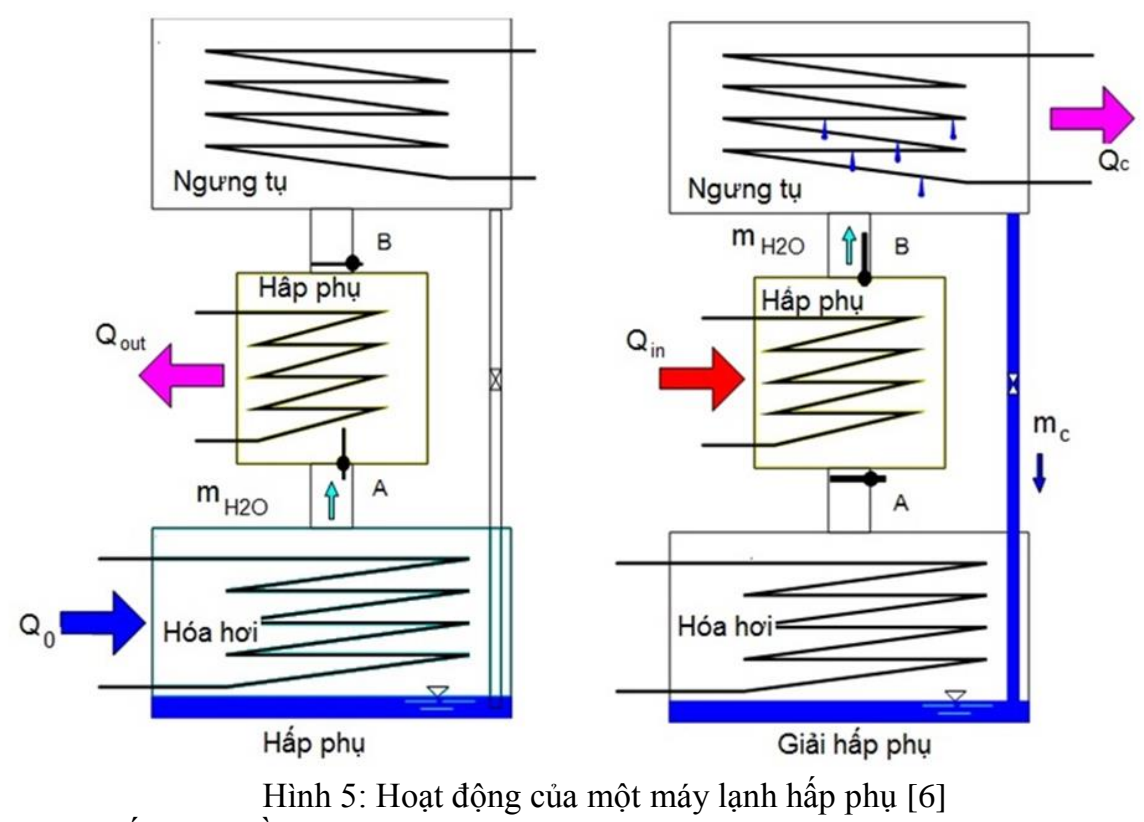

Quá trình hấp thụ hay hấp phụ đều được thực hiện theo nguyên lý nhiệt động học như sau: Nhiệt độ và áp suất chất hấp phụ và chất được hấp phụ là 2 thông số trạng thái phụ thuộc, nghĩa là với một giá trị của nhiệt độ thì tương ứng với một áp suất và ngược lại. Có thể coi bộ phận hấp phụ, một trong ba bộ phận của máy lạnh hấp phụ là "máy nén nhiệt". Qua quá trình cấp/thải nhiệt cho bộ phận hấp phụ là quá trình trao đổi năng lượng cần thiết để môi chất lạnh lưu động. Như vậy máy lạnh hấp phụ sẽ không sử dụng bơm dung dịch như trong máy lạnh hấp thụ.

Nguyên lý làm lạnh của máy lạnh hấp phụ cũng tương tự như trong máy lạnh hấp thụ, nhưng với chất hấp phụ không phải ở dạng dung dịch mà là một chất rắn, xốp có vô số lỗ hổng nhỏ li tị nên diện tích bề mặt của nó tiếp xúc với hơi của môi chất lạnh rất lớn.

Phần bên trái hình 5 , mô tả quá trình hấp phụ. Quá trình đó được tiến hành như sau: Sau khi môi chất lạnh hóa hơi, làm lạnh trong bộ phận hóa hơi thì van A mở, chất hấp phụ hút hơi môi chất lạnh (nước) vào nó. Nhiệt sinh ra trong quá trình hấp phụ sẽ được thải ra ngoài môi trường thông qua bộ trao đồi nhiệt. Trong quá trình hấp phụ thì van $\mathrm{B}$ đóng, van $\mathrm{A}$ mở (phía trái hình 5).

Khi chất hấp phụ đã no, nghĩa là hơi của môi chất lạnh đã chiếm hết các lỗ hổng của chất hấp phụ thì hơi đó cần phải được đưa ra ngoài chất hấp phụ đó, quá trình này được gọi là giải hấp phụ hay còn gọi là tái sinh chất hấp phụ. Trên hình 5 , phía bên phải mô tả quá trình giải hấp phụ. Khi đó, van $\mathrm{A}$ đóng đồng thời nhiệt lượng từ bên ngoài được cấp vào làm cho hơi môi chất lạnh thoát ra, qua van $\mathrm{B}$ rồi ngưng tụ thành lỏng trong bình ngưng. Môi chất lạnh trong bình ngưng với áp suất cao sẽ qua van tiết lưu giảm áp rồi hóa hơi, kết thúc 1 chu kỳ làm làm lạnh. Chu kỳ đó được lạ̣p lại liên tục. Như vậy quá trình hấp phụ và giải hấp phụ được tiến hành luân phiên nhau trong máy lạnh hấp phụ.

Để máy lạnh hấp phụ hoạt động liên tục, cần phải kết hợp 2 quá trình hấp phụ và giải hấp phụ luôn thực hiện đồng thời. Hình 6 là sơ đồ của một máy lạnh hấp phụ hoạt động liên tục. Hấp phụ và giải hấp phụ được 
tiến hành ở 2 buồng riêng biệt, khi buồng này làm nhiệm vụ hấp phụ thì buồng kia tiến hành giải hấp phụ đồng thời. Đó là, trong khi hơi môi chất lạnh được hút vào đầy chất hấp phụ thì nhiệt năng cấp vào ở nhiệt độ cao đưa vào buồng giải hấp phụ đẩy môi chất lạnh ra khỏi chất hấp phụ rồi ngưng tụ ở bình ngưng để qua van tiết lưu và hóa hơi, làm lạnh. Các quá trình này được luân phiên liển tục.

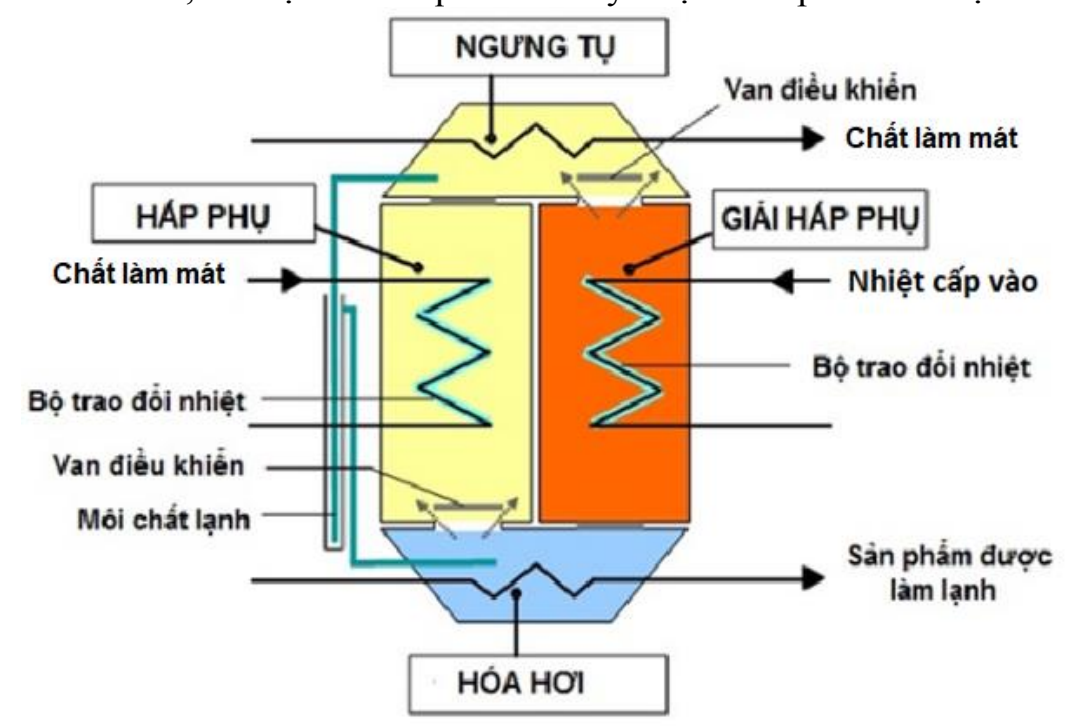

Hình 6: Sơ đồ của máy lạnh hấp phụ liên tục [7]

Như vậy, chu trình làm việc của máy lạnh hấp phụ liên tục là:

- Nhiệt năng cấp cho chất hấp phụ, đẩy hơi môi chất lạnh vào bình ngưng tụ.

- Hơi môi chất lạnh ngưng tụ, nhiệt ngưng tụ được thải ra ngoài qua bộ trao đổi nhiệt.

- Môi chất lạnh từ bình ngưng tụ qua tiết lưu vào bình hóa hơi, trở thành dạng hơi ở áp suất thấp, tương ứng nhiệt độ thấp.

- Hơi môi chất lạnh trong bình hóa hơi lại được hút vào chất hấp phụ, nhiệt do hấp phụ sinh ra sẽ được thải ra ngoài qua bộ trao đổi nhiệt.

\section{NHIẸT THẢI CỦA ĐộNG CƠ ĐỐT TRONG}

Trên cơ sở phân tích nguồn năng lượng cung cấp cho động cơ đốt trong, chúng ta sẽ đánh giá nhiệt thải ra của động cơ với các tải trọng khác nhau. Nhiên liệu cấp cho động cơ sẽ được biểu diễn thông qua hiệu suất hiệu dụng. Hình 7 biểu diễn quan hệ giữa hiệu suất hiệu dụng $\eta_{\mathrm{m}}$ và vận tốc trung bình của piston $\mathrm{v}_{\mathrm{k}}$ cho động cơ Diezel và Otto.

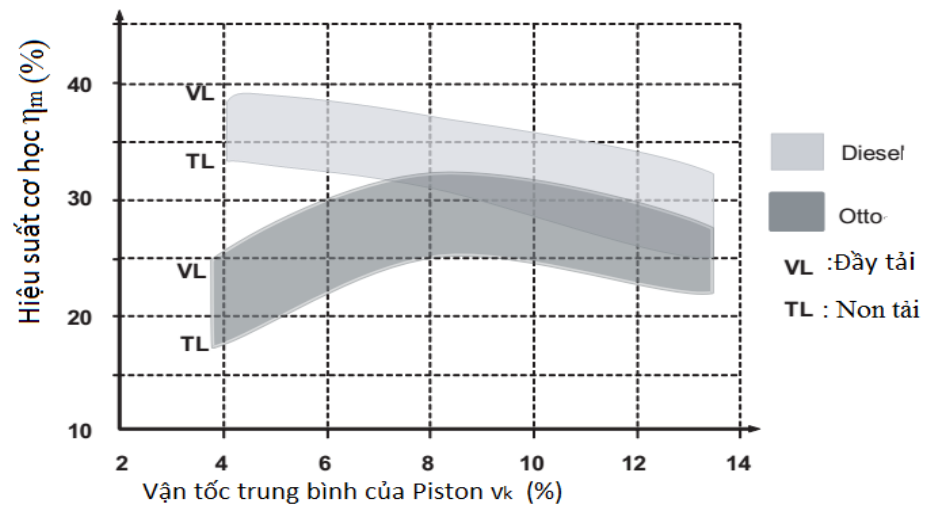

Hình 7: Quan hệ giữa hiệu suất của động cơ Diezel và Otto với vận tốc trung bình của piston [8]

Quan hệ giữa vận tốc trung bình $\mathrm{v}_{\mathrm{k}}$ với và hành trình của piston $\mathrm{L}_{\mathrm{k}}$ được biểu diễn theo phương trình sau:

$$
v_{k}=2 . n \cdot L_{k}
$$

Phổ của hiệu suất cơ hiệu dụng $\eta_{\mathrm{m}}$ biến đổi theo tải trọng của ôtô. Xe đầy tải có hiệu suất lớn hơn xe non tải. Quan hệ giữa hiệu suất này với công suất cơ học của động cơ $\mathrm{P}_{\mathrm{m}}$ được biểu diễn như sau: 


$$
\eta_{m}=\frac{P_{m}}{\dot{m}_{n l} H_{t}}
$$

Trong đó $\dot{m}_{n l}$ là lưu lượng nhiên liệu cấp cho động cơ, $\mathrm{H}_{\mathrm{t}}$ là nhiệt trị thấp của nhiên liệu.

Nghiên cứu của Pischinger và cộng sự [8] đã thiết lâp biểu đồ trên hình 7 , biểu thị quan hệ giữa hiệu suất động cơ với vận tốc chuyển động của piston. Từ biểu đồ, chúng ta nhận thấy rằng, động cơ Diezel có hiệu suất lớn hơn động cơ Otto. Ở vận tốc piston tối ưu, hiệu suất của động cơ Diezel nằm trong khoảng từ $34 \%$ đến $38 \%$, nhưng đối với động cơ Otto chỉ trong khoảng $25 \%$ đến $30 \%$.

Để xác định nhiệt thải của động cơ ôtô, chúng ta sẽ cân bằng năng lượng khi động cơ hoạt động ổn định. Gọi enthalpy của nhiên liệu đưa vào là $\dot{I}_{n l}$, của không khí là $\dot{I}_{k k}$, năng lượng sinh ra của động cơ là công cơ học $\mathrm{P}_{\mathrm{m}}$, enthalpy của khói thải là $\dot{I}_{k t}$ và các dạng năng lượng khác như ma sát khi piston chuyển động, nhiệt sinh ra do đốt cháy nhiên liệu, nhiệt làm mát cho động cơ là $\dot{Q}_{t}$. Phương trình cân bằng năng lượng sẽ là:

$$
\dot{I}_{n l}+\dot{I}_{k k}=P_{m}+\dot{I}_{k t}+\dot{Q}_{t}
$$

Ở mỗi công cơ học $\mathrm{P}_{\mathrm{m}}$ thì áp suất sản phẩm cháy trong xy lanh là $\mathrm{p}_{\mathrm{kt}}$. Như vậy $\mathrm{p}_{\mathrm{kt}}$ cũng là đại lượng đặc trưng cho công cơ học $\mathrm{P}_{\mathrm{m}}$. Đối với động cơ 4 kỳ có dung tích xy lanh $\mathrm{V}_{\mathrm{xl}}$, số vòng quay của động cơ $\mathrm{n}$ thì công cơ học $\mathrm{P}_{\mathrm{m}}$ được xác định theo công thức sau:

$$
P_{m}=\frac{V_{x l} \cdot p_{k t} \cdot n}{2}
$$

Kết quả nghiên cứu của Pischinger [8] về nhiệt năng thải loại của động cơ đốt trong đã được xác lập trên biểu đồ hình 8 .

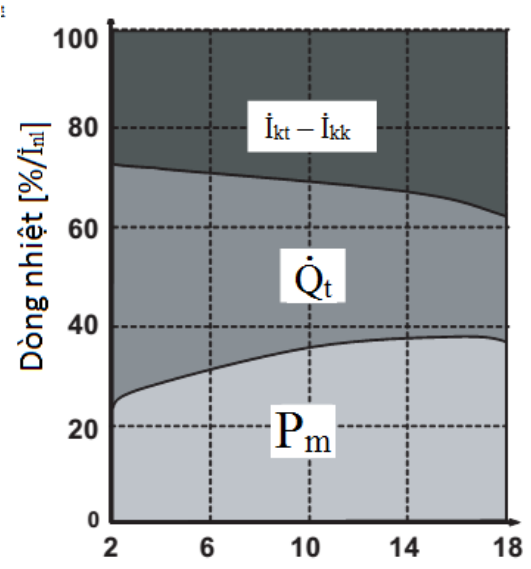

a) Áp suất khì trong $x y$ lanh $p_{k t}[$ bar]

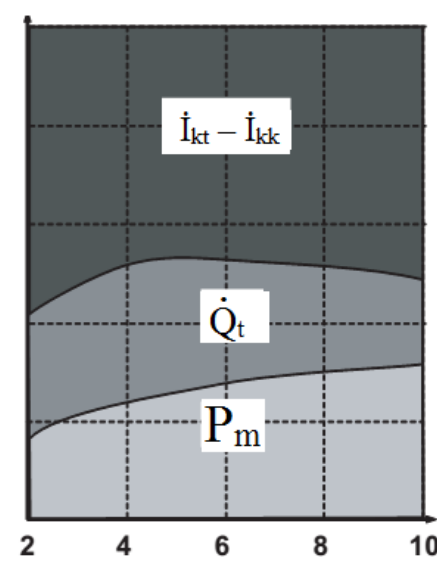

b) Áp suất khí trong xy lanh $\mathrm{p}_{\mathrm{kt}}[\mathrm{bar}]$ c) Số vòng quay $\mathrm{n}$ [1000/min]

Hình 8: Biểu đồ biểu diễn quan hệ giữa dòng nhiệt do nhiên liệu cấp cho động cơ Diezel (a), động cơ Otto (b) phụ thuộc vào áp suất khí trong xy lanh p $\mathrm{kt}_{\mathrm{k}}$ và với số vòng quay $\mathrm{n}$ của động cơ Otto khi đầy tải (c) [8].

Theo biểu đồ hình 8 thì nhiệt lượng thải của 2 loại động cơ là:

- Nhiệt lượng thoát ra từ khói thải $\dot{I}_{k t}-\dot{I}_{k k}$,

- Nhiệt lượng thoát ra từ quá trình làm mát động cơ $\dot{Q}_{t}$.

Nhiệt lượng thải này chiếm tỷ lệ rất lớn theo biểu đồ biểu diễn quan hệ giữa dòng nhiệt của động cơ đốt trong, cụ thể như sau: 
ĐỂ ĐIỀU HÒA KHÔNG KHÍ TRONG Ồ TÔ

Bảng 1: Tỷ lệ nhiệt thải theo biểu đồ hình 9

\begin{tabular}{|l|c|c|}
\hline \multicolumn{1}{|c|}{ Động cơ } & $\begin{array}{c}\text { Nhiệt lượng thoát ra từ khói thải } \\
\dot{I}_{k t}-\dot{I}_{k k}\end{array}$ & $\begin{array}{c}\text { Nhiệt lượng thoát ra từ quá trình } \\
\text { làm mát động cơ } \dot{Q}_{t}\end{array}$ \\
\hline Động cơ Diezel (a) & Khoảng $30 \%$ & Khoảng $35 \%$ \\
\hline Động cơ Otto (b) & Khoảng $50 \%$ & Khoảng $25 \%$ \\
\hline Động cơ Otto khi đầy tải (c) & Khoảng $50 \%$ & Khoảng $20 \%$ \\
\hline
\end{tabular}

Để tận dụng 2 nguồn nhiệt thải đó cho máy lạnh hấp phụ chúng ta sẽ lắp đặt bộ thu nhiệt thải, đó là thiết bị trao đổi nhiệt tại các vị trí thích hợp.

\subsection{Nguồn nhiệt từ khí thải}

Các loại ôtô hiện tại phải bảo đảm tiêu chuẩn khí thải Euro 4. Theo đó, đối với động cơ Otto phải có bộ lọc Katalysator 3 ngã, còn với động cơ Diezel thì Katalysator phải có chất xúc tác oxy hóa và bộ lọc muội (DPF). Nhiệt độ khí thải sau bộ lọc muội luôn lớn hơn $500^{\circ} \mathrm{C}$ [8]. Bộ thu nhiệt thải ngoài việc cung cấp nhiệt cho máy lạnh hấp phụ mà còn làm giảm bức xạ và hạn chế nhiệt thải ra môi trường. Sơ đồ bố trí bộ thu nhiệt thải từ khí thải của động cơ ôtô được biểu diễn trển hình 9.

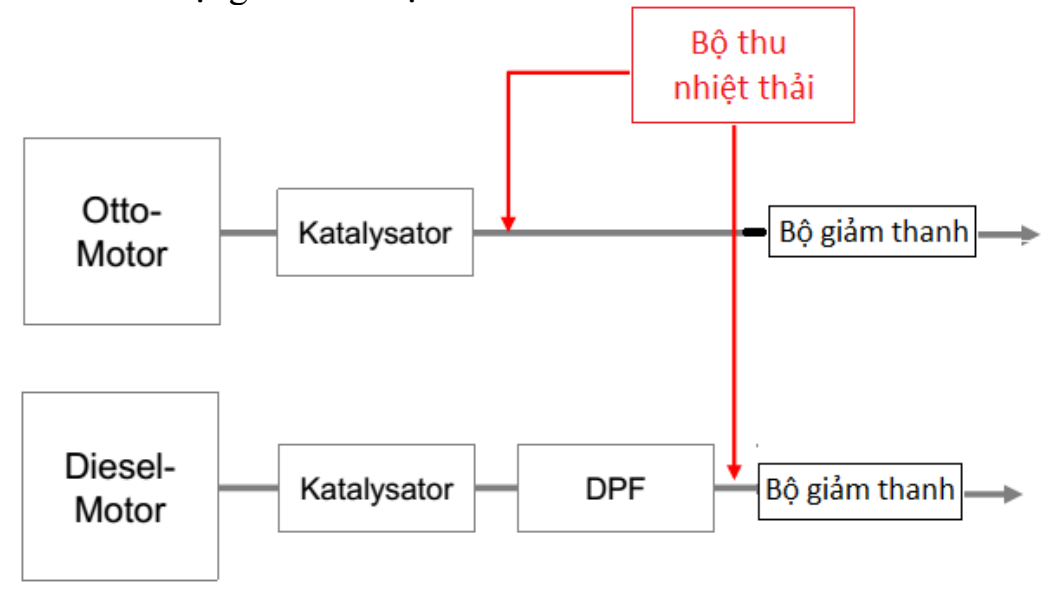

Hình 9: Sơ đồ bố trí bộ thu nhiệt trên đường khí thải của động cơ Otto và Diezel.

Lukas Enke [9] đã tiến hành đo nhiệt độ khí thải của động cơ Otto, nhiệt độ sau van thải có ký hiệu là t tkt và sau Katalysator với ký hiệu là t kat. Nhiệt độ tại các điểm đo này thay đổi theo vận tốc chuyển động của xe [10]. Quan hệ này được biểu diễn trên hình 10.

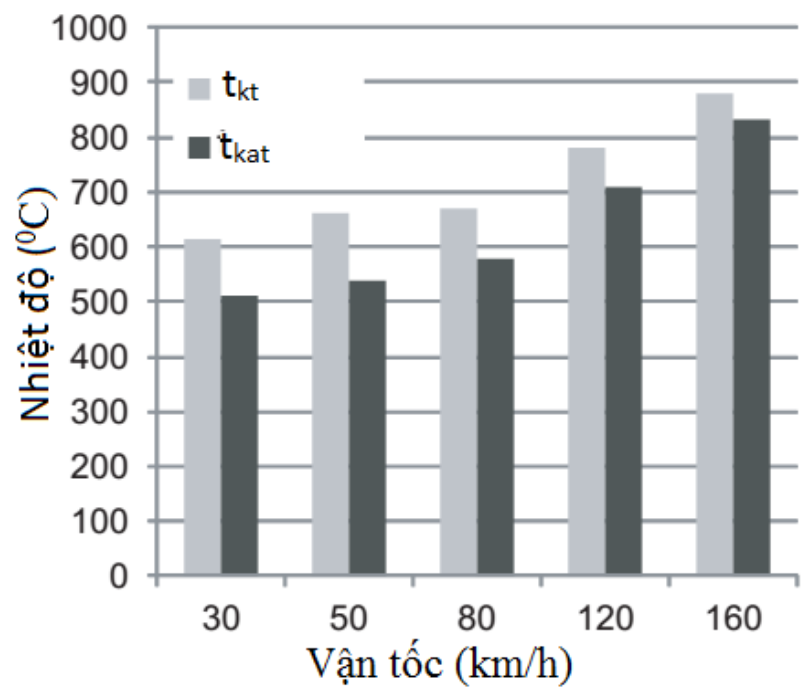

Hình 10: Quan hệ giữa vận tốc của xe có động cơ Otto với nhiệt độ khói thải sau van thải tkt và nhiệt độ khói thải sau katalytor. 


\section{MÁY LẠNH HÂP PHỤ SỬ DỰG NHIẸTT THẢI CỦA ĐỘNG CƠ ĐỐT TRONG ĐÊ ĐIỀU HÒA KHÔNG KHÍ TRONG Ổ TÔ}

Trên hình 11, biểu đồ biểu thị quan hệ giữa vận tốc và nhiệt độ khói thải cho thấy,tương ứng với vận tốc từ $30-160 \mathrm{~km} / \mathrm{h}$, nhiệt độ khí thải $\mathrm{t}_{\mathrm{kat}}$ có giá trị trong phạm vi từ $500^{\circ} \mathrm{C}$ đến hơn $820^{\circ} \mathrm{C}$. Do đó, nhiệt độ trung bình của khí thải $t_{\text {kat }}$ khoảng $624^{\circ} \mathrm{C}$. Như vậy, nhiệt độ khí thải $\mathrm{t}_{\text {kat }}$ tại vị trí đặt bộ thu nhiệt có nguồn nhiệt tiềm năng có thể cung cấp lượng nhiệt cần thiết cho hoạt động của máy lạnh hấp phụ.

\subsection{Nhiệt thải từ làm mát cho động co}

Các động cơ đốt trong đều phải có hệ thống làm mát hoàn chỉnh. Đó là thiết thiết bị trao đổi nhiệt có nhiệm vụ thu nhận nhiệt từ xylanh của động cơ và thu nhiệt của hộp bánh răng qua lưu động tuần hoàn của chất làm mát (thường là nước) để tải nhiệt ra môi trường. Sơ đồ bố trí thiết bị trao đổi nhiệt để làm mát động cơ được biểu diễn trên hình 11 .

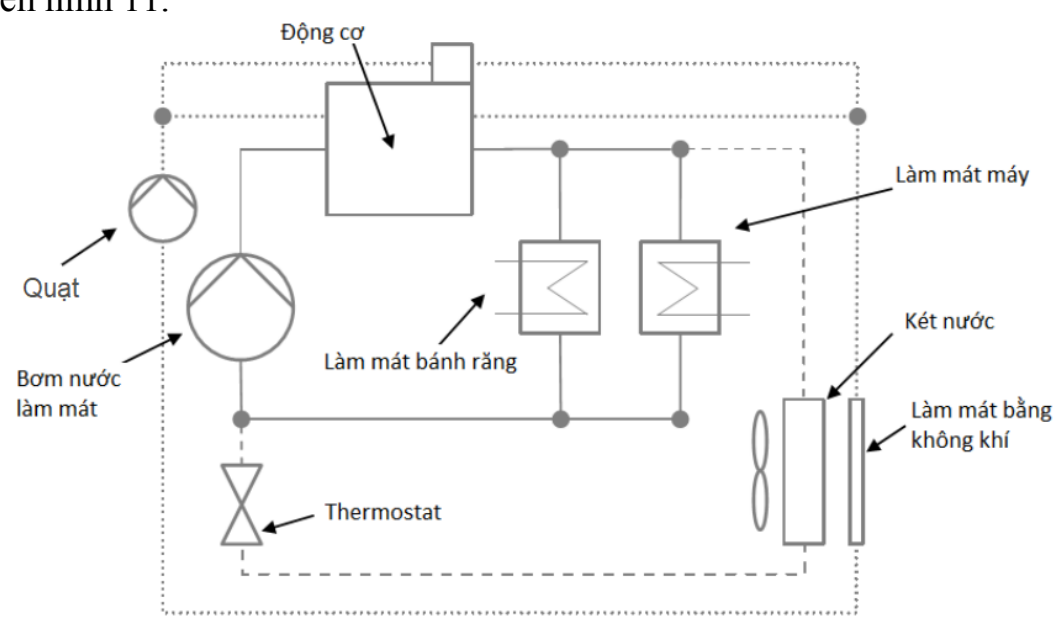

Hình 11: Sơ đồ thiết bị làm mát động cơ

Trên sơ đồ có 2 vòng tuần hoàn của nước, đó là vòng làm mát máy và vòng làm mát hộp bánh răng. Khi động cơ khởi động, vòng tuần hoàn làm mát bánh răng sẽ mang nhiệt của động cơ đến hâm nóng hộp bánh răng đến nhiệt độ cần thiết cho dầu bôi trơn hoạt động có hiệu quả. Khi nhiệt độ hâm nóng đạt đến giá trị cần thiết thì thermostat sẽ điều khiển để nước làm mát động cơ (theo đường gạch ngắt quảng) qua két nước rồi thải nhiệt ra ngoài. Thermostat còn đảm nhiệm điều khiển lưu lượng của bơm để duy trì nước làm mát ở trong khoảng $80^{\circ} \mathrm{C}$ đến $100^{\circ} \mathrm{C}$. Trên sơ đồ còn có đường chấm chấm là một vòng tuần hoàn không khí, được tích hợp cho những động cơ có tỷ số nén lớn nhằm nâng cao hiệu quả làm mát động cơ. Như vậy, nhiệt độ làm mát động cơ thải ra môi trường khá thấp nên hầu như không được tận dụng cho máy lạnh hấp phụ.

\section{3 Đề xuất phương án lắp đặt máy lạnh hấp phụ cho ô tô}

Trong máy lạnh hấp phụ, chu trình hoạt động của cặp môi chất là đặc trưng cơ bản của thiết bị làm lạnh này. Bảng 1 nêu một số thông số và đặc tính của một vài môi chất lạnh thường dùng có nhiệt độ hóa hơi ở $5^{\circ} \mathrm{C}$. Để bảo đảm an toàn cho hành khách, môi chất phải có nhiệt hóa hơi lớn và không ăn mòn kim loại thì nước là môi chất phù hợp nhất. Chất hấp phụ phù hợp với nước là LithiumBromit $(\mathrm{LiBr})$. Nhưng chất này sẽ gây ăn mòn cho thiết bị trao đổi nhiệt. Nghiên cứu của Chwarz và Gentner chỉ ra rằng, chất hẩp phụ rắn Zeolith hoặc Silikagel là thích hợp với môi chất lạnh là nước [11], [12].

Bảng 2: Thông số nhiệt vật lý của vài mô chất lạnh ở nhiệt độ hóa hơi $5^{0} \mathrm{C}$

\begin{tabular}{|l|c|c|c|c|}
\hline \multicolumn{1}{|c|}{ Môi chất } & $\mathrm{p}_{0}[\mathrm{bar}]$ & $\rho_{0}\left[\mathrm{~kg} / \mathrm{m}^{3}\right]$ & $\Delta \mathrm{i}_{0}[\mathrm{~kJ} / \mathrm{kg}]$ & Đặc tính \\
\hline Ammoniak & 5.157 & 4.115 & 1610 & Độc, có thể cháy \\
\hline Methanol & 0.055 & 0.078 & 1043 & Độc, dễ cháy \\
\hline Ethanol & 0.023 & 0.046 & 1151 & Dễ cháy \\
\hline Nước & 0.009 & 0.007 & 2510 & \\
\hline
\end{tabular}

Như trong phần 2 đã giới thiệu chu trình hoạt động của máy lạnh hấp phụ, để bảo đảm máy lạnh hoạt động liên tục chúng tôi lựa chọn máy lạnh 2 buồng như được biểu diễn trên hình 12 .

Theo sơ đồ máy lanh hấp phụ (a), máy lạnh hấp phụ 2 buồng có buồng bên phải là buồng hấp phụ, còn buồng bên trái là buồng giải hấp phụ và có nguyên lý hoạt động như sau:

* Xét về phía môi chất lạnh và chất hấp phụ: 
Sau khi môi chất lạnh (nước) hóa hơi đẳng áp, hơi môi chất áp suất thấp và nhiệt độ thấp đến buồng hấp phụ (buồng bên phải hình (a)), van dưới mở, van trên đóng, hơi được chất hấp phụ 2 hấp phụ đẳng tích. Quá trình hấp phụ kết thúc khi chất hấp phụ đã trở thành chất hấp phụ bão hòa (no) ở áp suất thấp ở điểm 1. Nhiệt sinh ra trong quá trình hấp phụ ở buồng hấp phụ sẽ được nhả nhiệt cho môi trường giải nhiệt là không khí. Sau quá trình hấp phụ, cả 2 van ở buồng hấp phụ đều đóng và chất hấp phụ ở trạng thái đó được hâm nóng cho đên áp suất ngưng tụ tại điểm 2 . Trong quá trình hâm nóng, nhiệt độ và áp suất của chất hấp phụ đã bão hòa đó tăng lên, môi chất (nước) trong chất hấp phụ bay hơi ra khỏi chất hấp phụ. Như vậy, kết thúc quá trình 1-2 là đến quá trình giải hấp phụ.

Khi chất hấp phụ 1 đã no ở buồng giải hấp phụ (buồng bên trái hình (a)) được cấp nhiệt từ khí thải (đường màu đỏ) thực hiện quá trình nhận nhiệt đẳng áp giải hấp phụ làm cho hơi môi chất lạnh thoát ra khỏi chất hấp phụ ở áp suất cao. Tại thời điểm này, van dưới đóng, van trên mở, hơi môi chất lạnh đi vào bộ phận ngưng tụ. Tại dàn ngưng, hơi môi chất nhả nhiệt đẳng áp cho môi trường giải nhiệt ngưng tụ thành lỏng bão hòa ở áp suất cao. Quá trình ngưng tụ kết thúc tại điểm 3. Môi chất lạnh sau khi ngưng tụ sẽ đi theo đường màu xanh qua tiết lưu tiết lưu đẳng entanpy thành môi chất lạnh ở áp suất thấp và nhiệt độ thấp điểm 4. Sau đó đi qua buồng hóa hơi, môi chất nhận nhiệt đẳng áp từ mồi trường cần làm lạnh và hóa hơi thành hơi môi chất lạnh áp suất thấp và nhiệt độ thẩp. Khép kín chu trình và chu trình cứ thế tiếp diễn.à chu trình cứ thế tiếp diễn.

Còn phía chất hấp phụ, sau khi hơi môi chất thoát ra khỏi chất hấp phụ, chất hấp phụ thành chưa bão hòa (chưa no) ở áp suất cao điểm 5 được không khí môi trường giải nhiệt làm giảm nhiệt độ và áp suất thành chất hấp phụ chưa bão hòa (chưa no) ở áp suất thấp ở điểm 6 . Sau đó, chất hấp phụ tiếp tục được hạ nhiệt độ do quá trình hấp phụ đẳng áp hơi môi chất lạnh đạt trạng thái bão hòa (no) ở nhiệt độ thấp. Và chu trình cứ thế tiếp diễn.

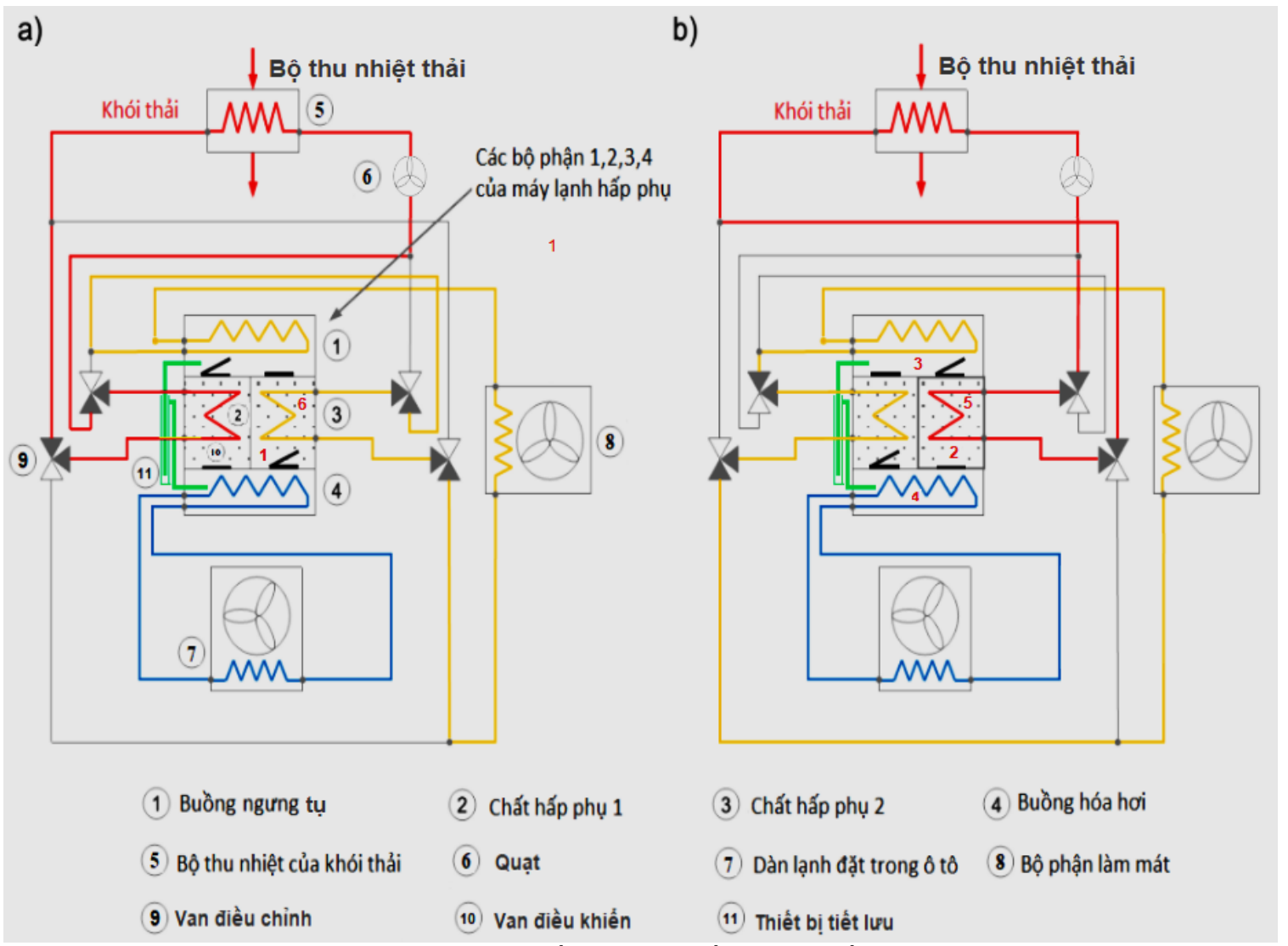

Hình 12: Sơ đồ máy lạnh hấp phụ 2 buồng

(a) (b) Chu trình hoạt động của máy lạnh hấp phụ trong đó hai buồng hấp phụ và giải hấp phụ làm việc luân phiên - Hấp phụ (Đường màu vàng), - Giải hấp phụ (Đường màu đỏ).

* Xét về phía khí thải: (đường màu đỏ) 
Khí thải trong bộ thu nhiệt sẽ qua van điều chỉnh đi đến buồng giải hấp phụ nhả nhiệt cho chất hấp phụ 1 làm cho hơi môi chất thoát ra khỏi chất hấp phụ. Sau khi nhả nhiệt, khí thải qua van điều chỉnh rồi được quạt hút về bộ thu nhiệt tiếp tục nhận nhiệt. Khép kín chu trình và chu trình cứ thế tiếp diễn.

* Xét về phía không khí giải nhiệt cho quá trình hấp phụ và buồng ngưng tụ: (đường màu vàng)

Quá trình hấp phụ sẽ tỏa nhiệt. Nhiệt lượng hấp phụ sinh ra sẽ được không khí qua quạt tải ra ngoài. Sau đó, không khí lại qua van điều chỉnh đi đến buồng ngưng. tụ Tại đây, không khí nhận nhiệt làm mát hơi môi chất rồi quay về bộ phận làm mát, nhả nhiệt ra môi trường xung quanh. Và quá trình cứ thế tiếp diễn. Sơ đồ máy lanh hấp phụ (b), máy lạnh hấp phụ 2 buồng có nguyên lý hoạt động ngược lại, buồng bên phải là buồng giải hấp phụ, còn buồng bên trái là buồng hấp phụ.

Theo nghiên cứu của Amir Sharafifian, Majid Bahrami [13], Li Zhi Zhang và Ling Wang [3], biểu diễn được chu trình lý tưởng của máy lạnh hấp phụ trên biểu đồ $\mathrm{p}-\mathrm{T}$ theo đường đẳng tích và đẳng áp, có các nhiệt độ và áp suất như sau:

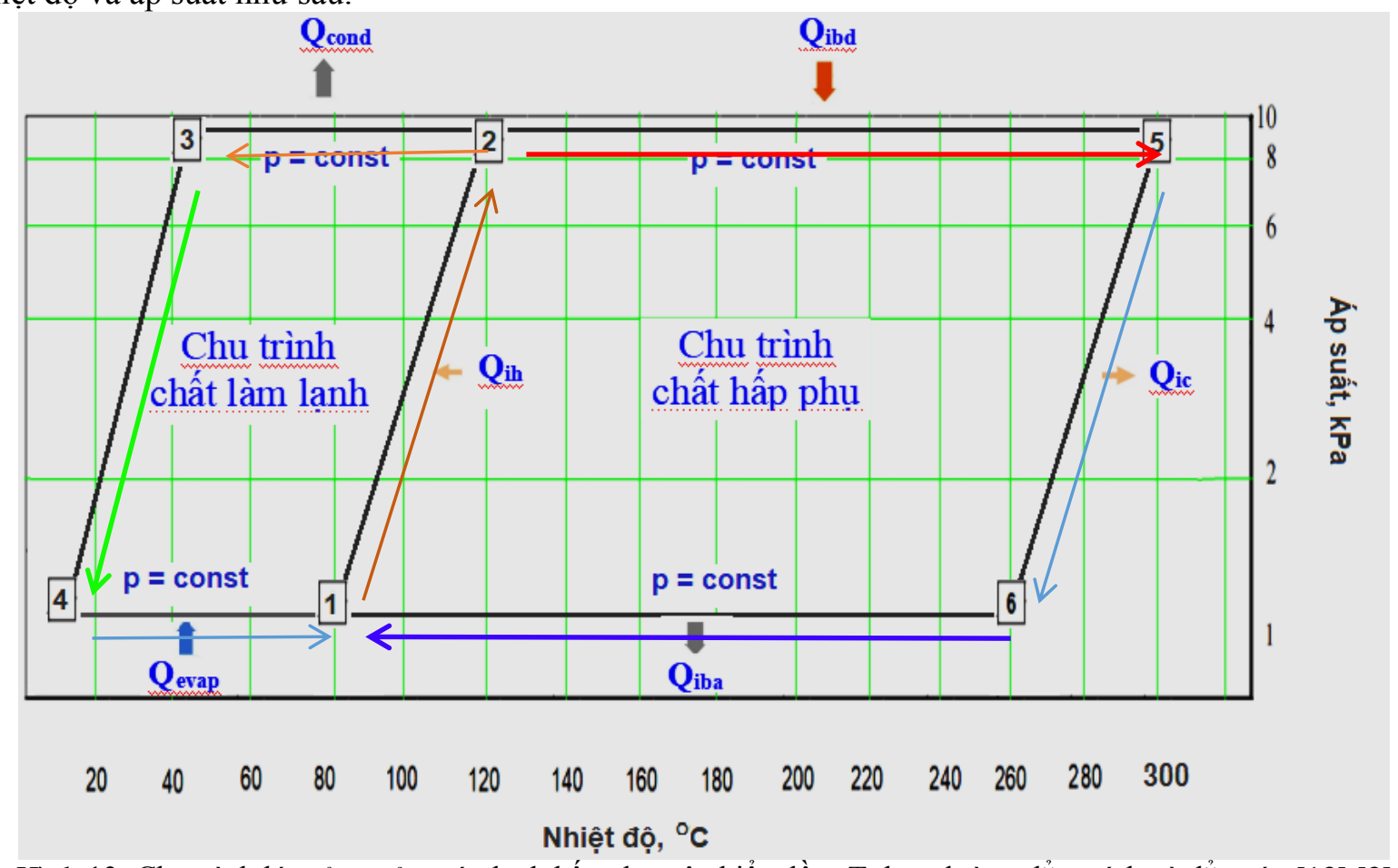

Hình 13: Chu trình lý tưởng của máy lạnh hấp phụ trên biểu đồ p-T theo đường đẳng tích và đẳng áp [13],[3]

Trong đó:

Trạng thái của các điểm đặc trưng trên chu trình của máy lạnh hấp phụ:

+ Điểm 1: Chất hấp phụ ở trạng thái bão hòa (no), nước lấp đầy các lỗ hổng của chất hấp phụ.

+ Điểm 2: Hơi nước thoát ra khỏi chất hấp phụ ở áp suất cao, nhiệt độ cao;

+ Điểm 3: Môi chất lạnh (nước) sau ngưng tụ ở thể lỏng ở áp suất cao và nhiệt độ cao.

+ Điểm 4: Môi chất lạnh (nước) ở thể lỏng qua tiết lưu đi vào buồng hóa hơi ở áp suất thấp;

+ Điểm 5: Chất hấp phụ không no ở áp suất cao, nhiệt độ cao;

+ Điểm 6: Chất hấp phụ không no ở áp suất thấp và nhiệt độ thấp

Các quá trình trong chu trình là:

- Quá trình 1 - 2: Tại điểm 1, chất hấp phụ đã được môi chất lạnh (nước) lấp đầy các lỗ hổng của chất hấp phụ, hay nói cách khác là chất hấp phụ đã bão hòa (no), sẽ nhận nhiệt $\mathrm{Q}_{\mathrm{in}}$ đẳng tích làm tăng nhiệt độ và áp suất hơi môi chất.

- Quá trình 2 - 3: Quá trình ngưng tụ đẳng áp, hơi môi chất lạnh chuyển pha sang pha lỏng ở áp suất cao.

- Quá trình 3 - 4: Quá trình tiết lưu đẳng entanpy, tiết lưu môi chất lạnh ở thể lỏng đưa vào buồng lạnh. Quá trình này tương ứng với đường cong biểu diễn trạng thái hơi bão hòa của nước. Trên đường này, điểm 3 ứng với trạng thái lỏng bão hòa, điểm 4 là hơi bão hòa ẩm. 
- Quá trình 4 - 1: Quá trình hóa hơi đẳng áp, môi chất lạnh chuyển sang pha hơi ở áp suất thấp, làm lạnh ở buồng lạnh.

- Quá trình 2 - 5: Quá trình nhận nhiệt đẳng áp để giải hấp phụ, tái sinh chất hấp phụ.

- Quá trình 5 - 6: Quá trình nhả nhiệt đẳng tích làm mát chất hấp phụ, là bước đầu chuẩn bị cho quá trình hấp phụ của máy lạnh.

- Quá trình 6 - 1: Quá trình hấp phụ đẳng áp, chất hấp phụ hấp phụ hơi môi chất lạnh đạt trạng thái bão hòa (no), nhiệt hấp phụ $\mathrm{Q}$ được tải ra ngoài.

Thông số của các điểm đặc trưng và nhiệt lượng trên chu trình của máy lạnh hấp phụ:

$+\mathrm{T}_{1}$ : Nhiệt độ chất hấp phụ bão hòa (no) tại buồng hấp phụ ở áp suất thấp, ${ }^{\circ} \mathrm{C}$

$+\mathrm{T}_{2}$ : Nhiệt độ chất hấp phụ bão hòa (no) tại buồng hấp phụ ở áp suất cao, ${ }^{\circ} \mathrm{C}$

$+\mathrm{T}_{3}$ : Nhiệt độ ngưng tụ ở buồng ngưng tụ, ${ }^{\circ} \mathrm{C}$

$+\mathrm{T}_{4}$ : Nhiệt độ bay hơi ở buồng bay hơi, ${ }^{\circ} \mathrm{C}$

$+\mathrm{T}_{5}$ : Nhiệt độ chất hấp phụ ở buồng giải hấp phụ, ${ }^{\circ} \mathrm{C}$

$+\mathrm{Q}_{\text {evap }}$ : Nhiệt lượng môi chất lạnh nhận được ở thiết bị bay hơi, ${ }^{\circ} \mathrm{C}$

$+\mathrm{Q}_{\text {cond }}$ : Nhiệt lượng môi chất lạnh thải ra ở thiết bị ngưng tụ, ${ }^{\circ} \mathrm{C}$

+ Qin (isosteric heating) : Nhiệt lượng nhận được ở buồng hấp phụ trong quá trình cấp nhiệt đẳng tích để bắt đầu quá trình giải hấp phụ, $\mathrm{kJ}$

+ Qibd (Isosbaric desorption heat) : Nhiệt lượng nhận được ở buồng hấp phụ trong quá trình cấp nhiệt đẳng áp để giải hấp phụ, $\mathrm{kJ}$

+ Qheat (Heating) : Nhiệt lượng được cấp từ khí thải của xe Otto ở buồng giải hấp phụ, kJ

$$
\mathrm{Q}_{\text {heat }}=\mathrm{Q}_{\mathrm{ih}}+\mathrm{Q}_{\mathrm{ibd}}
$$

$+\mathrm{Q}_{\mathrm{ic}}$ (isosteric cooling) : Nhiệt lượng thải ra ở buồng giải hấp phụ trong quá trình tải nhiệt đẳng tích để bắt đầu quá trình hấp phụ, $\mathrm{kJ}$

+ Qiba (isosbaric adsorption) : Nhiệt lượng thải ra ở buồng giải hấp phụ trong quá trình tải nhiệt đẳng áp để hấp phụ, $\mathrm{kJ}$

+ Q cool (Cooling heat) : Nhiệt lượng tải ra ở buồng hấp phụ, $\mathrm{kJ}$

\section{4 Lựa chọn phương thức tính toán}

$$
\mathrm{Q}_{\text {cool }}=\mathrm{Q}_{\text {ic }}+\mathrm{Q}_{\mathrm{iba}}
$$

Qua những mô tả trên đây, chúng ta nhận thấy rằng, nhiều nhân tố ảnh hưởng đến hoạt động của máy lạnh hấp phụ sử dụng nhiệt thải của động cơ ô tô đó là:

- Vận tốc của ô tô luôn thay đổi, kéo theo thay đổi tải trọng của động cơ và làm thay đổi lượng nhiệt cấp cho máy lạnh.

- Hệ số trao đổi nhiệt giữa môi chất lạnh và chất hấp phụ thay đổi theo tỷ lệ giữa khối lượng môi chất trong chất hấp phụ và khối lượng chất hấp phụ. Tỷ lệ này thay đổi liên tục trong quá trình háp phụ và giải hấp phụ làm cho lượng nhiệt cấp cho hoạt động của máy lạnh sẽ không ổn định.

- Sự đóng và mở các van điều khiển trong cả 2 buồng gây nên tổn thất áp suất, ảnh hưởng đến hoạt động của máy lạnh. Thêm vào đó, thời gian đóng và mở các van làm thay đổi thời gian hoạt đông của chu kỳ hấp phụ và giải hấp phụ, dẫn đến quá trình truyền nhiệt và truyền khối trong máy lạnh không ổn định.

Quá trình tính toán cho máy lạnh hấp phụ trong trường hợp này cần phải đưa ra nhiều giả thiết đơn giản hóa các nhân tố ảnh hưởng đến hoạt động của máy. Một vài tác giả như Andreas Gassel, [7], Syed Muztuza Ali, Anutosh Chakraborty [14] đã sử dụng chương trình TRNSYS, [15] B. Shi, A. Elsayed [23] sử dụng CFD để tính nhưng kết quả cũng sai lệch so với đo đạc thực tế.

Trong khuôn khổ bài này, chúng tôi trình bày tính toán định hướng dựa trên chu trình lý tưởng của Amir Sharafifian, Majid Bahrami [13], Li Zhi Zhang và Ling Wang [3] được thể hiện trên hình 13.

Để đánh giá hiệu quả của chu trình hấp phụ, hệ số làm lạnh COP được tính theo công thức sau:

$$
C O P=\frac{Q_{\text {evap }}}{Q_{\text {heat }}},
$$

Trong quá trình hấp phụ, nhiệt lượng nhận được được tính bằng tổng nhiệt lượng nhận được ở buồng hấp phụ trong quá trình cấp nhiệt đẳng tích để bắt đầu quá trình giải hấp phụ và nhiệt lượng nhận được ở buồng hấp phụ trong quá trình cấp nhiệt đẳng áp để giải hấp phụ theo công thức như sau [15] : 


$$
\begin{aligned}
& Q_{\text {heat }}=\left(m_{z}\left(c_{p z}+c_{p, l i q} w_{\text {max }}\right)+m_{b} c_{b}\right) \frac{d T}{d t}-m_{z} q_{s t} \frac{d w}{d t} \\
& Q_{\text {heat }}=\left(m_{z}\left(c_{p z}+c_{p, l i q} w_{\text {max }}\right)+m_{b} c_{b}\right)\left(T_{5}-T_{1}\right)-m_{z} q_{s t} k_{m}\left(w_{e q}-w\right),
\end{aligned}
$$

Trong đó: $\quad \mathrm{m}_{\mathrm{z}}$ là khối lượng của chất hấp phu, $\mathrm{kg}$

$\mathrm{c}_{\mathrm{pz}}$ là nhiệt dung riêng đẳng áp của chất hấp phụ Zeolite, $\mathrm{kJ} /(\mathrm{kg} . \mathrm{K})$,

$\mathrm{c}_{\mathrm{p}, \text { liq }}$ là nhiệt dung riêng đẳng áp của nước, $\mathrm{kJ} /(\mathrm{kg} . \mathrm{K})$

$\mathrm{W}_{\max }$ là lượng hơi nước hấp phụ lớn nhất trên $1 \mathrm{~kg}$ chất hấp phụ,

( $\mathrm{kg} / \mathrm{kg}$ chất hấp phụ khô)

$\mathrm{m}_{\mathrm{b}}$ là khối lượng của buồng hấp phụ, $\mathrm{kg}$

$\mathrm{c}_{\mathrm{b}}$ là nhiệt dung riêng của buồng hấp phụ, $\mathrm{kJ} /(\mathrm{kg} \cdot \mathrm{K})$

$\mathrm{W}_{\mathrm{eq}}$ là lượng hơi nước hấp phụ trên $1 \mathrm{~kg}$ chất hấp phụ bão hòa, $\mathrm{kg} / \mathrm{kg}$ chất hấp phụ khô

w là lượng hơi nước hấp phụ trên $1 \mathrm{~kg}$ chất hấp phụ, $\mathrm{kg} / \mathrm{kg}$ chất hấp phụ khô

$\mathrm{q}_{\mathrm{st}}$ là nhiệt cấp trong quá trình đẳng tích, $\mathrm{kJ} / \mathrm{kg}$

$\mathrm{k}_{\mathrm{m}}$ là hệ số truyền khối

Theo nghiên cứu của Amir Sharafian, Majid Bahrami [13] cho thấy nhiệt dung riêng đẳng áp của chất hấp phụ Zeolite $\mathrm{c}_{\mathrm{pz}}$ là $0,836 \mathrm{~kJ} /(\mathrm{kg} . \mathrm{K})$.

Theo nghiên cứu của Li Zhi Zhang và Ling Wang [3], các thông số được sử dụng như sau:

Bảng 3: Thông số được sử dụng để tính toán [3]

\begin{tabular}{|c|c|c|}
\hline Ký hiệu & Giá trị & Đơn vi \\
\hline $\mathbf{T}_{\mathbf{1}}$ & 80 & ${ }^{\circ} \mathrm{C}$ \\
$\mathbf{T}_{\mathbf{3}}$ & 45 & ${ }^{\circ} \mathrm{C}$ \\
$\mathbf{T}_{\mathbf{4}}$ & 10 & ${ }^{\circ} \mathrm{C}$ \\
$\mathbf{T}_{\mathbf{5}}$ & 300 & ${ }^{\circ} \mathrm{C}$ \\
$\mathbf{Q}_{\text {evap }}$ & 4911.7 & $\mathrm{~kJ}$ \\
$\mathbf{m}_{\mathbf{z}}$ & 17 & $\mathrm{~kg}$ \\
$\mathbf{m}_{\mathbf{b}}$ & 7.1 & $\mathrm{~kg}$ \\
$\mathbf{c}_{\mathbf{b}}$ & 0.47 & $\mathrm{~kJ} /(\mathrm{kg} \cdot \mathrm{K})$ \\
\hline
\end{tabular}

Như vậy muốn tính được nhiệt lượng nhận được trong quá trình hấp phụ, cần phải tính được các thông số

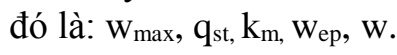

Theo các công thức [3], $\mathrm{w}_{\text {eq }}$ là lượng hơi nước hấp phụ trên $1 \mathrm{~kg}$ chất hấp phụ bão hòa được tính như sau:

$$
\begin{aligned}
& \ln \left(p_{z}\right)=a\left(w_{e q}\right)+b\left(w_{e q}\right) / T_{z}, \\
& a\left(w_{e q}\right)=a_{o}+a_{1} w_{e q}+a_{2} w_{e q}^{2}+a_{3} w_{e q}^{3}, \\
& b\left(w_{e q}\right)=b_{o}+b_{1} w_{e q}+b_{2} w_{e q}^{2}+b_{3} w_{e q}^{3},
\end{aligned}
$$

Trong đó: $\quad \mathrm{T}_{\mathrm{z}}$ là nhiệt độ của chất hấp phụ bão hòa, $\mathrm{T}_{\mathrm{z}}=\mathrm{T}_{1}=353 \mathrm{k}$

$\mathrm{P}_{\mathrm{z}}$ là áp suất tương ứng ở nhiệt độ $\mathrm{T}_{\mathrm{z}}$, mbar

Do quá trình 4-1 là quá trình hóa hơi đẳng áp, môi chất lạnh chuyển sang pha hơi ở áp suất thấp, làm lạnh ở buồng lạnh nên: $\mathrm{p}_{\mathrm{z}}=\mathrm{p}_{\mathrm{s}}=\mathrm{p}_{4}$. Do đó, tra áp suât $\mathrm{p}_{\mathrm{Z}}$ chính là áp suất sôi tương ứng với nhiệt độ $\mathrm{T}_{4}, \mathrm{~K}$.

Áp suất bão hòa của chất hấp phụ được tính bằng công thức:

$$
\ln \left(P_{s}\right)=a_{s}+b_{s} T
$$

Với: $\mathrm{a}_{\mathrm{s}}, \mathrm{b}_{\mathrm{s}}$ là các hằng số, $\mathrm{a}_{\mathrm{s}}=20.5896$ và $\mathrm{b}_{\mathrm{s}}=-5089.26[3] ; \mathrm{T}_{4}=283 \mathrm{~K}$

$a_{0}, a_{1}, a_{2}, a_{3}, b_{0}, b_{1}, b_{2}, b_{3}$ là các hằng số có giá trị như sau: [13]

$\mathrm{a}_{0}=14.8979, \mathrm{a}_{1}=95.408, \mathrm{a}_{2}=-636.66, \mathrm{a}_{3}=1848.8$

$b_{o}=-7698.85, b_{1}=21498.1, b_{2}=-184598.0, b_{3}=512605.0$

Từ (10),(11),(12), và các thông số trên, giải phương trình bậc 3 , tìm ra được $\mathrm{w}_{\mathrm{eq}}=0.2$, còn $\mathrm{w}_{\max }$ tương tự như cách tính $\mathrm{w}_{\mathrm{eq}}$ nhưng tương ứng điểm 2 ở áp suất cao $\mathrm{p}_{2}=0,095$ bar nên $\mathrm{w}_{\max }=0.23$ 
Từ $\mathrm{w}_{\mathrm{eq}}, \mathrm{b}\left(\mathrm{w}_{\mathrm{eq}}\right)$ và $\mathrm{R}$ là hằng số khí lý tưởng với $\mathrm{R}=\mathrm{M}_{\mathrm{Z}} / \mathrm{R}_{\mathrm{u}}=8.314 /\left(0.018^{*} 1000\right)=0.462 \mathrm{~kJ} /(\mathrm{kg} \cdot \mathrm{K})[13]$, nhiệt cấp trong quá trình đẳng tích có công thức:

$$
\begin{aligned}
& q_{s t}=-R b\left(w_{e q}\right) \\
& q_{s t}=-R^{*}\left(b_{o}+b_{1} w_{e q}+b_{2} w_{e q}^{2}+b_{3} w_{e q}^{3}\right)
\end{aligned}
$$

Và còn lại là $\mathrm{k}_{\mathrm{m}}$ hệ số truyền khối được tính theo công thức [3] sau đây:

$$
k_{m}=\frac{15 D_{s}}{R_{p}^{2}}
$$

Với: $\mathrm{D}_{\mathrm{s}}$ là sức căng bề mặt được tính như sau: $D_{s}=D_{s 0} \exp \left(-\frac{E_{a}}{R T_{z}}\right)$

Từ công thức (16) và (17) có công thức đơn giản như sau:

Trong đó:

$$
k_{m}=k_{1} \exp \left(-\frac{k_{2}}{T_{z}}\right)
$$

Theo bảng các hằng số [13], đối với chất hấp phụ là Zeolite13X-water, được: $\mathrm{k}_{1}=0.04004(1 / \mathrm{s})$ và $\mathrm{k}_{2}=$ $905.8(\mathrm{~K})$. Từ đó, tìm được $\mathrm{k}_{\mathrm{m}}$, từ $\mathrm{k}_{\mathrm{m}}$ tìm được lượng hơi nước hấp phụ trên $1 \mathrm{~kg}$ chất hấp phụ:

$$
w=w_{e q}\left[1-\exp \left(-k_{m} t\right)\right]
$$

Như vậy nhiệt lượng nhận được trong quá trình hấp phụ được tính như sau :

$$
Q_{\text {heat }}=\left(m_{z}\left(c_{p z}+c_{p, l i q} w_{\text {max }}\right)+m_{b} c_{b}\right)\left(T_{5}-T_{1}\right)-m_{z} q_{s t} k_{m}\left(w_{e q}-w\right)
$$

Từ công thức [7]-[23], tìm được hệ số làm lạnh của chu trình hấp phụ COP có giá trị là 0.41 [3]

\section{KẾT LUẦN}

Nhằm mục đích tận dụng nhiệt thải của động cơ ôtô, chúng tôi đã khảo sát nhiệt lượng thải ra từ động cơ ôtô để cung cấp cho máy lạnh hấp phụ hoạt động. Bài viết cũng đã phân tích, lựa chọn phương pháp làm lạnh, cặp môi chất phù hợp với hoạt động của xe ôtô và tính toán định hướng theo chu trình. Tận dụng nhiệt thải cũng là biện pháp tiết kiệm nhiên liệu, góp phần làm giảm lượng khí $\mathrm{CO}_{2}$ thải ra môi trường, làm chậm quá trình biến đồi khí hậu.

Vấn đề cần nghiên cứu thêm là kết cấu của bộ thu nhiệt từ khí thải và cách sắp xếp chất hấp phụ trong thiết bị này để có thể đưa vào ứng dụng trong thực tế. Bên cạnh đó, hướng phát triển của phần nghiên cứu này là theo hướng thực nghiệm để đưa ra những thông số chính xác nhằm tính toán được công suất của từng thiết bị trong máy lạnh hấp phụ, tác động của máy lạnh hấp phụ đến môi trường và chi phí đầu tư.

\section{TÀI LIỆU THAM KHẢO}

[1]. Cổng thông tin điện tử về môi trường: http://mt.gov.vn, Ô tô, xe máy gây ô nhiễm không khí nghiêm trọng, 07/06/2011.

[2]. De Boer R, Smeding SF, Mola S, Silicagel-water adsorption cooling prototype system for mobile air conditioning. Heat Powered Cycles Conf., Berlin, Germany, 2009 \& erde M, Corberan JM, de Boer R, Smeding S. Modelling of a waste heat driven silica gel/water adsorption cooling system comparison with experimental results. Int. Sorption Heat Pump, Padua, Italy: 2011.

[3]. Li Zhi Zhang và Ling Wang, Performance estimation of an adsorption cooling system for automobile waste heat recovery, Research Institute of Internal Combustion Engine, Dalian University of Technology. Dalian, China, 1997.

[4]. Hans-Martin Henning u.a. Kuehlen und Klimatisieren mit Waerme. Hrsg. von Fraunhofer IRB Verlag. Karlsruhe, 2016. 


\section{MÁY LẠNH HẤP PHỤ SỬ DƯNG NHIẸTT THẢI CỦA ĐÔ̂NG CƠ ĐỐT TRONG ĐÊ ĐIỀU HÒA KHÔNG KHÍ TRONG Ổ TÔ}

[5]. Sybille Dallapiccola, Abwärmenutzung zur Kälteerzeugung mittels Absorptionskälteanlagen, Uni Dornbirn, Januar 2017.

[6]. Siegfried Kreussler and Detlef Bolz, Experiments on solar adsorption refrigeration using zeolite and water, Laboratory for Solar Energy, University of Applied Sciences Luebeck, Germany.

[7]. Andreas Gassel, Die Adsorptionskältemaschine Betriebserfahrungen, thermodynamische Modell und TRNSYSSimulation, Institut für Thermodyn. und Technische Gebäudeausrüstung, TU Dresden.

[8]. Pischinger, R.; Klell, M. ; Sams, T. ; List, H. (Hrsg.), Thermodynamik der Verbrennungskraftmaschine. 3. Springer, 2009.

[9]. Lukas Enke, Analyse des unterstützenden Einsatzes einer Adsorptionskälteanlage für die PKW-Klimatisierung, Fakultät für Maschinenbauder Technischen Universtität Carolo-Wilhelmina zu Braunschweigluận, oktober 2014.

[10]. Barrault, S ; Benouali, J ; Clodic, D, Analysis of the economic and environmental consequences of a phase out or considerable reduction leakage of mobile air conditioners. In: Final Report 30001 Ecole des Mines de Paris/Armines(2003), S. 53.

[11]. Schwarz, J. ; Maier-Laxhuber, P. ; Woerz, R.: Cooling and air conditioning with water/zeolite in Proceedings of the 1993 non-fluorocarbon insulation, refrigeration and air conditioning technology workshop, 1993, S. 27-29

[12]. Gentner, H.: Vergleichende Untersuchung von mechanisch, elektrisch und thermisch angetriebenen Kälteanlagen zur Fahrzeugklimatisierung, Technische Universität München, Dissertation, 1995.

[13]. Amir Sharafifian, Majid Bahrami, Critical analysis of thermodynamic cycle modeling of adsorption cooling systems for light-duty vehicle air conditioning applications, Laboratory for Alternative Energy Conversion (LAEC), School of Mechatronic Systems Engineering, Simon Fraser University, 2015.

[14]. Syed Muztuza Ali, Anutosh Chakraborty, Thermodynamic Modelling and Performance Study of an Engine Waste Heat, , Nanyang Technological University, Singgapor, 2015

[15]. B. Shi, A. Elsayed, R.K. AL-Dadah, S. Mahmoud, CFD Simulation of Honeycomb Adsorption Bed for Automotive Cooling System, Proceedings of the International Conference on Heat Transfer and Fluid Flow,Prague, Czech Republic, August 2014.

[16]. Siegfried Kreussler and Detlef Bolz, experiments on solar adsorption refrigeration using zeolite and water, Laboratory for Solar Energy, University of Applied Sciences Luebeck, Germany.

[17]. Constanze Bongs, Experimentelle und mathematisch-numerische Untersuchung von verdunstungsgekühlten, sorptiv beschichteten Wärmeübertragern für die Luftentfeuchtung und kühlung, Uni Aachen, 2014.

[18]. Sybille Dallapiccola, Abwärmenutzung zur Kälteerzeugung mittels Absorptionskälteanlagen, Uni Dornbirn, Januar 2017.

[19]. Technologien zur solaren Kühlung in Wohngebäuden weltweit und in Gebäuden des sozialen Wohnungsbaus in Mexiko, Uli Jakob, Paul Kohlenbach, GIZ Oktober 2017.

[20]. Fundamentals of Engineering Thermodynamics, 7e

[21]. Motoyuki Suzuki, Application of adsorption cooling systems to automobiles, Institute of Industrial Science, University of Tokyo, 7-22-1 Ropponsi, Minato-ku, Tokyo 106, Japan, 1993.

[22]. Amirhossein Sharafianardakani, Waste heat-driven adsorption cooling systems for vehicle air conditioning applications, Luận án tiến sỹ tại Simon Fraser university, 2015.

Ngày nhận bài: 15/11/2020

Ngày chấp nhận đăng: 04/03/2021 